\title{
SURVEY OF RESPIRATORY SYMPTOMS, SPIROMETRY, AND RAST AND THEIR RELATION TO OCCUPATIONAL EXPOSURES AMONG DETERGENT PRODUCTS STAFF
}

\author{
By \\ ${ }^{1}$ IbraheemTM, ${ }^{2}$ Momen M and ${ }^{2}$ Mostafa NS \\ ${ }^{1}$ Department of Chest,${ }^{2}$ Department of Community, Environmental \& Occupational Medicine, \\ Faculty of Medicine, Ain Shams University, Cairo, Egypt.
}

\begin{abstract}
:
Introduction: Respiratory disorders are one of the documented hazards affecting workers involved in the industry of washing products. Aim of Work: This study aims to assess the frequency of sensitization to enzymes in detergent industry. It also describes work-related respiratory symptoms and pulmonary function parameters among detergent workers in a detergent plant in Cairo, Egypt. Materials and Methods: A cross sectional study was carried out on all plant workers, where Radioallergosorbent testing (RAST) positive subjects underwent further detailed history taking, clinical examination, x-ray and pulmonary function measurements. Results: Among 1329 workers, $9 \%$ of them were sensitized using RAST. Of those, $56.8 \%$ reported chest complaints. The RAST grading of workers revealed that $39.2 \%$ of workers were grade I, $24 \%$ were grade II and 36.8 were grade III. It was found that $75.2 \%$ of them were exposed to hazardous materials during work. The majority of them reported exposure to dusts and powders $(58.4 \%)$. Pulmonary functions testing revealed that $52 \%$ showed restrictive lesions and $2.4 \%$ obstructive lesions. The majority of workers who had obstructive and restrictive lesions were RAST grade III (66.7 \% and 52.3\% respectively where $\mathrm{P}<0.001$ ). By Comparing pulmonary functions of workers with dust exposure, it was evident that the majority of workers who had obstructive and restrictive lesions were exposed to dust within the workplace, $100 \%$ and $83.1 \%$ respectively $(\mathrm{P}<0.034)$. The study of pulmonary functions among different RAST grades revealed a statistically significant lowered mean of FVC, FVC percentage and FEV1 among grade III workers than other grades $(\mathrm{P}<0.001)$. Conclusion: Dust exposure in detergent producing plant has a negative impact on workers' respiratory systems.
\end{abstract}

Keywords: Detergent products, Occupational exposure, RAST, Respiratory, Spirometry. 


\section{Introduction}

The respiratory health effects have been documented in workers exposed to a variety of occupational exposures in small and large-scale industries during their processing. Respiratory disorders caused by occupational exposures are influenced by the type of offending dust, dose, duration of exposure and genetic factors (Subbarao et al, 2009)

Hazardous substances used in washing products including enzymes and powder are respiratory sensitizers and are known to cause allergic rhinitis and occupational asthma among working staffs. It is also an irritant and may give rise to short term or long term respiratory disorder up to chronic bronchitis (Dykewicz, 2009)

Some cases were detected in accordance with high level of enzyme concentration in the surrounding environment (Vanhanen et al, 2000). Others were associated with low environmental monitoring of enzyme dust. This suggested the presence of other allergens apart from enzymes in detergent industry (Schweigert et al, 2000, Sarlo and Kirchner, 2002, Sarlo, 2003, Basketter et al, 2010).
Immunological assessment of workers exposed to cleaning and washing products was done using allergy blood testing which has excellent reproducibility; high specificity and sensitivity too, when compared to skin prick testing (Hamilton, 2010)

In occupational respiratory disorders, dynamic lung functions measurements by means of spirometry is beneficial. Lung function parameters are considered a cornerstone in the early recognition of pulmonary dysfunctions even if the workers may be clinically normal (Cotes, 1979).

\section{Aim of Work}

To assess the frequency of sensitization to enzymes in detergent industry. It also describes work-related respiratory symptoms and pulmonary function parameters among detergent workers in a detergent plant in Cairo, Egypt.

\section{Materials and Methods}

- Study design: It is a cross sectional study.

- Place and duration of study: This study was carried out on a detergent producing plant during the period from November 2014 to January 2015. 
- Study sample: All the staff (1329 workers) in the plant was examined.

\section{- Study methods:}

A. All workers underwent Radioallergosorbent testing (RAST) which is a method employed in allergy testing (type 1 allergy - IgE mediated). The patient's serum is incubated with a solid phase allergen and the amount of occupational allergen-specific $\operatorname{IgE} \quad$ is quantified with radiolabelled anti-IgE. By means of RAST, 119 workers (9 \%) were documented to be sensitized. Those workers continued the study.

B. All of them were interviewed by a physician who filled a questionnaire including questions on occupational history, respiratory symptoms, and smoking status of the study participants. The occupational histories of the study participants were assessed through questions on previous and current job, work duration, job description, working conditions, methods of ventilation conditions, and personal protective equipments. Respiratory symptoms (cough, expectoration, dyspnea, wheezing, and chest tightness) were documented.

C. General and local examination of all body systems on emphasize of the respiratory system were carried out for all participants.

D. Weight and height of the study participants were measured and their body mass index (BMI) was calculated.

E. Investigations:

1- Lung function parameters; Forced vital capacity (FVC), Forced expiratory volume in the first second (FEV1), FEV1/FVC, Forced Expiratory Flow at $25-75 \%$ (FEF 25-75) and Peak expiratory flow rate (PEF) were measured using digital COSMED spirometer. Predicted values for each worker were calculated using his/her gender, age and height. $80 \%$ of predicted values were the cutoff point.

2- Plain chest $X$ ray (both posteroanterior and lateral views) was done 
for the examined group. If abnormal findings were present, CT chest was performed.

\section{Data analysis:}

All data was revised, coded, tabulated and introduced to a PC using Statistical package for Social Science (2001). Suitable descriptive statistics were done; Mean, standard deviation ( \pm SD), minimum and maximum values (range) for numerical data and frequency and percentage for nonnumerical data. The IndependentSamples T Test was used to assess the statistical significance of the difference between two study group means, ChiSquare test was used to examine the relationship between two qualitative variables, Fisher's exact test was used to examine the relationship between two qualitative variables when there's a cell with an expected frequency of less than 5, and One-Way ANOVA test was used to assess the statistical significance of the difference between more than two study group means. $\mathrm{P}<0.05$ was considered significant and $\mathrm{P}<0.01$ was considered highly significant.

\section{Consent:}

Administrative approval of the detergent plant was obtained. The study participants were assured of the confidentiality of the data and their verbal consent was obtained.

\section{Funding:}

No funding sources for this research.

\section{Ethical Approval:}

The study protocol was approved by the department of Community, Environmental \&Occupational Medicine, Faculty of Medicine, Ain Shams University, Cairo, Egypt.

\section{Results}

This study was carried out on 1329 male workers in a detergent factory who underwent RAST testing. One hundred and nineteen (9\%) workers were RAST positive and continued the rest of the study. 
Table (1): General characteristics of the studied workers

\begin{tabular}{|c|c|c|c|c|}
\hline & & & $\mathrm{N}$. & Percent $(\%)$ \\
\hline \multirow{2}{*}{ Age (years) } & \multicolumn{2}{|c|}{ Mean \pm SD } & \multicolumn{2}{|c|}{$38.3 \pm 6.6$} \\
\hline & \multicolumn{2}{|l|}{ Range } & \multicolumn{2}{|c|}{$23-56$} \\
\hline \multirow{3}{*}{ Smoking status } & \multicolumn{2}{|l|}{ Non smoking } & 62 & 49.6 \\
\hline & \multicolumn{2}{|l|}{ Smoker } & 46 & 36.8 \\
\hline & \multicolumn{2}{|l|}{ Ex-smoker } & 17 & 13.6 \\
\hline \multirow{9}{*}{ Complaints } & \multirow{8}{*}{$\begin{array}{c}\text { Chest } \\
\text { complaints }\end{array}$} & Overall & 71 & 56.8 \\
\hline & & Dyspnea on effort & 31 & 24.8 \\
\hline & & Expectoration & 18 & 14.4 \\
\hline & & Cough & 12 & 9.6 \\
\hline & & Wheezes & 4 & 3.2 \\
\hline & & Pain & 6 & 4.8 \\
\hline & & Sneezing & 5 & 4 \\
\hline & & Allergy & 21 & 16.8 \\
\hline & \multicolumn{2}{|c|}{ Rhinitis } & 67 & 53.6 \\
\hline \multirow{8}{*}{ Dust exposure } & \multicolumn{2}{|c|}{ Unexposed } & 31 & 24.8 \\
\hline & \multirow{7}{*}{ Exposed } & Overall & 94 & 75.2 \\
\hline & & Packaging materials & 1 & 0.8 \\
\hline & & Dusts and powders & 73 & 58.4 \\
\hline & & Liquid chemicals & 11 & 8.8 \\
\hline & & Enzyme exposure & 2 & 1.6 \\
\hline & & Carbonates - sulphates & 7 & 5.6 \\
\hline & & - odor smells & 1 & \\
\hline \multirow{3}{*}{ RAST grade } & \multicolumn{2}{|l|}{ Grade I } & 49 & 39.2 \\
\hline & \multicolumn{2}{|l|}{ Grade II } & 30 & 24 \\
\hline & \multicolumn{2}{|l|}{ Grade III } & 46 & 36.8 \\
\hline \multirow{4}{*}{ Pulmonary functions } & \multicolumn{2}{|l|}{ Normal } & 55 & 44 \\
\hline & \multicolumn{2}{|l|}{ Obstructive } & 3 & 2.4 \\
\hline & \multicolumn{2}{|l|}{ Restrictive } & 65 & 52 \\
\hline & \multicolumn{2}{|l|}{ Mixed } & 2 & 1.6 \\
\hline \multirow{2}{*}{ Small airways affection } & \multicolumn{2}{|l|}{ Yes } & 123 & 98.4 \\
\hline & \multicolumn{2}{|l|}{ No } & 2 & 1.6 \\
\hline \multirow{3}{*}{ Recommendation } & \multicolumn{2}{|c|}{ Repeat after $1-3$ months } & 62 & 49.6 \\
\hline & No recommen & tion & 50 & 40 \\
\hline & Remove from & posure & 13 & 10.4 \\
\hline
\end{tabular}

RAST $=$ Radioallergosorbent test 
Table (1) shows that the mean age of the group ( \pm SD) was $38.3( \pm 6.6)$ years, with a prevalence of smoking among them was $36.8 \%$. It was reported that $75.2 \%$ of them were exposed to hazardous materials in work (dust and powders, liquid chemicals, enzymes...). Chest complaints were reported by $56.8 \%$ workers where the most common manifestation was dyspnea on efforts and expectoration. Pulmonary functions testing of workers revealed a prevalence of restrictive lesions among of $52 \%$ of workers.

Radiological examination in the form of x-ray revealed that all of them were normal except one worker showed reticulo-nodular pattern. On further investigation, he showed moderate restrictive pattern on spirometry and he was diagnosed as interstitial lung disease.

Table (2): Spirometry study findings of workers

\begin{tabular}{|c|c|c|c|c|}
\hline & Mean & 吕D & Minimum & Maximum \\
\hline FVC & 3.9 & 0.94 & 2.0 & 6.7 \\
\hline FVC $\%$ & 76.4 & 17.6 & 3.9 & 124.0 \\
\hline FEV1 & 3.5 & 0.7 & 1.6 & 5.3 \\
\hline FEV1/FVC Ratio & 90.3 & 7.6 & 69.2 & 100.0 \\
\hline PEF & 9.1 & 11.4 & 2.9 & 97.8 \\
\hline FEF 25-75 & 4.4 & 1.3 & 1.6 & 8.8 \\
\hline
\end{tabular}

$\mathrm{FEV}_{1}=$ Forced expiratory volume in the first second, $\mathrm{FVC}=$ Forced vital capacity, $\mathrm{PEF}=$ Peak Expiratory Flow, FEF25-75= Forced Expiratory Flow between 25\% and 75\% of FVC

Description of some lung function parameters was shown in Table (2), where $\mathrm{FEV}_{1}$ / FVC ratio range from $69.2 \%$ up to $100 \%$. 
Table (3): Comparative study between types of respiratory disease as diagnosed by spirometry testing and RAST grades among studied workers

\begin{tabular}{|c|c|c|c|c|c|c|c|c|}
\hline \multirow{2}{*}{\multicolumn{3}{|c|}{$\begin{array}{c}\text { Normal }(n=55) \\
\text { Obstructive }(n=3)\end{array}$}} & \multicolumn{4}{|c|}{ Pulmonary function } & \multirow[b]{2}{*}{$X^{2}$} & \multirow[b]{2}{*}{$\mathrm{P}$} \\
\hline & & & \multirow{2}{*}{$\begin{array}{c}\begin{array}{c}\text { Restrictive } \\
(\mathrm{n}=65)\end{array} \\
28\end{array}$} & \multirow{2}{*}{$\frac{\text { Mixed }(n=2)}{0}$} & \multirow[b]{2}{*}{20} & \multirow[b]{2}{*}{1} & & \\
\hline & $\mathrm{C}$ & No & & & & & \multirow{6}{*}{19} & \multirow{6}{*}{$<0.001^{*}$} \\
\hline & Tialde & $\%$ & $50.9 \%$ & $0.0 \%$ & $30.8 \%$ & $50.0 \%$ & & \\
\hline RAST & \multirow{2}{*}{ Grade II } & No & 18 & 1 & 11 & 0 & & \\
\hline \multirow{3}{*}{ grade } & & $\%$ & $32.7 \%$ & $33.3 \%$ & $16.9 \%$ & $0.0 \%$ & & \\
\hline & \multirow{2}{*}{ Grade III } & No & 9 & 2 & 34 & 1 & & \\
\hline & & $\%$ & $16.4 \%$ & $66.7 \%$ & $52.3 \%$ & $50.0 \%$ & & \\
\hline
\end{tabular}

*: Highly Significant difference

Comparison of pulmonary functions of workers with RAST grades revealed that the majority of workers who had obstructive and restrictive lesions were RAST grade III (66.7 $\%$ and $52.3 \%$ respectively where $\mathrm{P}<0.001$ ) (Table 3 ).

Table (4): Comparative study between types of respiratory disease as diagnosed by pulmonary functions testing and dust exposure among studied workers

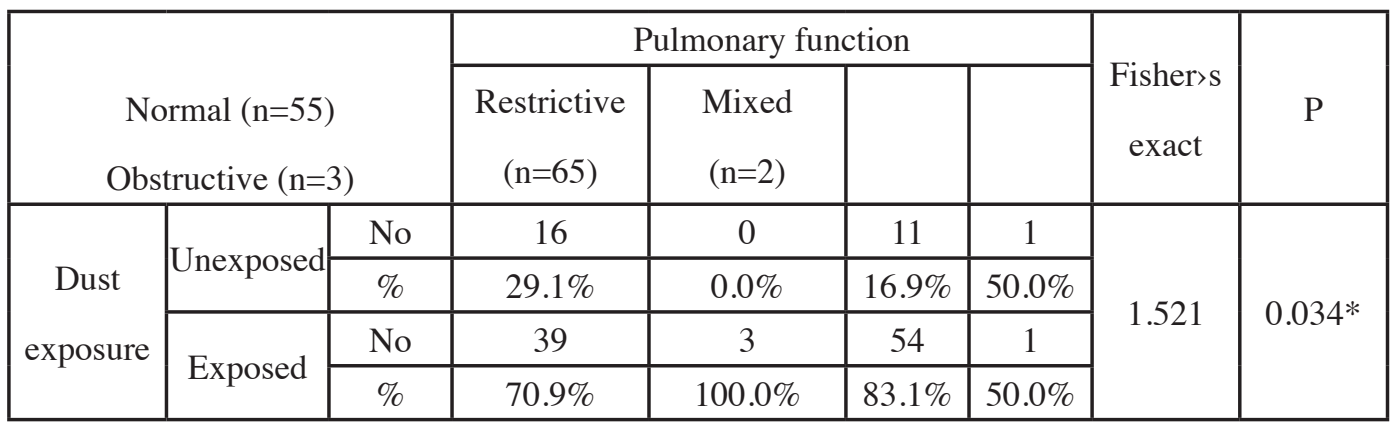

*: Highly Significant difference

Table 4 showed that the non-exposed group who didn't report exposure to any hazardous material during work, were compared to exposed workers regarding chest complaints and spirometry. By comparison of pulmonary functions of workers with dust exposure, it was evident that the majority of workers who had restrictive lesions and all of the workers who had obstructive were exposed to dust within workplace, $100 \%$ and $83.1 \%$ respectively $(\mathrm{P}<0.034)$. 
Table (5): Comparative study between pulmonary functions and RAST grades among studied workers

\begin{tabular}{|c|c|c|c|c|c|c|}
\hline & & No & Mean & SD & $\mathbf{F}^{\S}$ & $\mathbf{P}$ \\
\hline \multirow{3}{*}{$\mathrm{FVC}$} & Grade I & 46 & 4.0 & 0.8 & \multirow{3}{*}{11.284} & \multirow{3}{*}{$0.001 *$} \\
\hline & Grade II & 28 & 4.3 & 1.0 & & \\
\hline & Grade III & 45 & 3.4 & 0.9 & & \\
\hline \multirow{3}{*}{$\mathrm{FVC} \%$} & Grade I & 46 & 80.1 & 14.8 & \multirow{3}{*}{6.889} & \multirow{3}{*}{$0.001 *$} \\
\hline & Grade II & 28 & 81.9 & 22.6 & & \\
\hline & Grade III & 45 & 69.1 & 14.2 & & \\
\hline \multirow{3}{*}{ FEV1 } & Grade I & 46 & 3.6 & 0.6 & \multirow{3}{*}{9.197} & \multirow{3}{*}{$0.000 *$} \\
\hline & Grade II & 28 & 3.8 & 0.8 & & \\
\hline & Grade III & 45 & 3.1 & 0.7 & & \\
\hline \multirow{3}{*}{$\begin{array}{c}\text { FEV1/FVC } \\
\text { Ratio }\end{array}$} & Grade I & 46 & 90.4 & 6.7 & \multirow{3}{*}{0.705} & \multirow{3}{*}{0.496} \\
\hline & Grade II & 28 & 88.9 & 8.5 & & \\
\hline & Grade III & 45 & 91.0 & 7.9 & & \\
\hline \multirow{3}{*}{ PEF } & Grade I & 46 & 9.7 & 13.0 & \multirow{3}{*}{1.005} & \multirow{3}{*}{0.369} \\
\hline & Grade II & 28 & 11.1 & 16.4 & & \\
\hline & Grade III & 45 & 7.4 & 2.0 & & \\
\hline \multirow{3}{*}{ FEF25-75 } & Grade I & 46 & 4.6 & 0.9 & \multirow{3}{*}{2.478} & \multirow{3}{*}{0.088} \\
\hline & Grade II & 28 & 4.7 & 1.6 & & \\
\hline & Grade III & 45 & 4.1 & 1.4 & & \\
\hline
\end{tabular}

*: Highly Significant difference

$\S$ ANOVA test

The study of pulmonary functions among different RAST grades revealed a statistically significant lowered mean of FVC, FVC percentage and FEV1 among grade III workers than other grades $(\mathrm{P}<0.001)$ (Table 5). 
Table (6): Comparative study between presence of chest complaints and dust exposure among studied workers

\begin{tabular}{|c|c|c|c|c|c|c|}
\hline \multirow{2}{*}{\multicolumn{3}{|c|}{$\begin{array}{l}\text { Present }(n=67) \\
\text { Absent }(n=52)\end{array}$}} & \multicolumn{2}{|c|}{ Chest complaints } & \multirow{2}{*}{$X^{2}$} & \multirow{2}{*}{$\mathrm{P}$} \\
\hline & & & & & & \\
\hline \multirow{4}{*}{$\begin{array}{c}\text { Dust } \\
\text { exposure }\end{array}$} & \multirow{2}{*}{ Unexposed } & $\mathrm{N}$. & 14 & 15 & \multirow{4}{*}{1} & \multirow{4}{*}{0.215} \\
\hline & & $\%$ & $20.9 \%$ & $28.8 \%$ & & \\
\hline & \multirow{2}{*}{ Exposed } & N. & 53 & 37 & & \\
\hline & & $\%$ & $79.1 \%$ & $71.2 \%$ & & \\
\hline
\end{tabular}

By comparing the presence of chest complaints among the studied workers according to their exposure, it was found that there is no statistical difference between exposed and unexposed groups regarding their symptoms (Table 6).

\section{Discussion}

Working in the industry of detergents exposes the workers to dust, powders, liquid chemicals and other materials as proved by the current study where the overall exposure rate among RAST positive workers was $75.2 \%$ of them. Some studies mentioned that dust concentration is high during mixing and packing of detergents (Vanhanen et al, 2000, Vanhanen, 2010, Van Rooy, 2009).

Using RAST, we found that $119(9 \%)$ of the plant workers were sensitized to the used enzymes .The frequency of enzyme sensitization was similar to a study done in Denmark by Johnsen et al, 1997.
Although Detergent enzymes have a very good safety profile as mentioned by researches (Basketter, 2012). Material Safety Data Sheet mentioned that inhalation of dust/aerosols may induce sensitization in susceptible individuals or may cause irritation of the respiratory tract (Fishersci, 2014). Regarding the workers> complaints, $76 \%$ of the studied workers reported work related symptoms where 57\% were chest symptoms. Almost similar results were reported in Nigeria (87\%) and lower rate in Finland (22\%) (Vanhanen, 2010 ). Those findings may be explained by the fact that Finland is a developed country where lines of hazard prevention and health education of workers on symptoms of work 
related respiratory disorders might take place. Chest complaints were reported by $56.8 \%$ of the workers and the most common manifestation was dyspnea on efforts and expectoration $(24.8 \%$ and $14.4 \%$ respectively). The current study revealed that $53.6 \%$ of workers reported rhinitis. Similar rates were reported in Nigeria by Babashani et al, 2008 $(57 \%)$ and in Finland by Vanhanen, 2010 (47\%). At the same time, another study in Finland (Vanhanen et al, 2000) reported higher rates of rhinitis $(89 \%)$. Other studies reported higher prevalence of itching nose, sneezing and wheezing among exposed workers but a rate lower than the current study (Van Rooy, 2009).

Our research work revealed that restrictive and obstructive lesions among workers were associated with dust exposure $(61 \%$ and $34 \%$ among exposed workers respectively) with a statistical significant difference $(\mathrm{P}<0.034)$.

Similarly in Nigeria, Bamidele (2002) and Oleru (1984) concluded that the significantly lower value of some respiratory function measurements among production workers of detergent industry might be due to the exposure to some materials used in industry. FEV1, FVC and PEFR were significantly reduced among exposed detergent workers (Babashani et al, 2008, Oleru, 1984). While others didn't find any abnormality in the respiratory function testing due to enzyme exposure (Cathcart, 1997)

In the current study, no association was found between exposure to hazardous materials during work and chest symptoms. On the contrary, other studies revealed a positive relation between symptoms and dust exposure (Van Rooy et al, 2009).

\section{Conflict of interest}

Authors have declared that no conflict of interests exists.

\section{References}

1. Babashani M, Iliyasu Z and Ukoli CO (2008): Respiratory symptoms and pulmonary function impairment among detergent plant workers in Jos, Northern Nigeria. Niger J Med. OctDec;17(4):423-7

2. Bamidele JO (2002): Respiratory symptoms and peak expiratory flow rates in workers of a Nigerian soap and detergent industry Niger $\mathbf{J}$ Med; 11: 122-6.

3. Basketter D, Berg N, Kruszewski FH, Sarlo K and Concoby B (2012): The toxicology and immunology of detergent enzymes .J Immunotoxicol; 9(3):320-6. 
4. Basketter DA, Broekhuizen C, Fieldsend M, et al (2010): Defining occupational and consumer exposure limits for enzyme protein respiratory allergens under REACH Toxicology; 268: 165-70

5. Cathcart M, Nicholson P, Roberts D, Bazley M, Juniper C, Murray P and Randell M (1979): Enzyme exposure, smoking and lung function in employees in the detergent industry over 20 years. Medical Subcommittee of the UK Soap and Detergent Industry Association. Occup Med (Lond); 47(8):473-8.

6. Cotes JE (1979): Lung Function Assessment and Application in Medicine, forth ed., Blackwell Scientific Publications, London.

7. Dykewicz MS (2009): Occupational asthma: current concepts in pathogenesis, diagnosis, and management. J Allergy Clin.Immunol ; 123:519-28.

8. Fishersci S (2014): Material Safety Data Sheet, Enzymes. Available at: http://www. fishersci.com/ecomm/servlet/msdsproxy ? productName $=\mathrm{BP} 26745$ and productDes cription $=$ PROTEASE $+\mathrm{S}+\mathrm{AUREUS}+\mathrm{V}-$ 8+5MGandcatNo=BP2674-5andvendorld=VN 00033897 andstoreld $=10652$. Accessed on 20/2/2015.

9. Hamilton RG (2010): Proficiency Survey-Based Evaluation of Clinical Total and AllergenSpecific IgE Assay Performance. Arch Pathol Lab Med ; 134: 975-82

10. Johnsen CR, Sorensen TB, Larsen AI, Secher AB, Andreasen E, Kofoed GS, Nielsen LF and Gyntelberg F (1979): Allergy risk in an enzyme producing plant: a retrospective follow up study. Occup Environ Med ; 54(9): 671-5.

11. Oleru UG (1984): Pulmonary function of exposed and control workers in a Nigerian non- soapy detergent factory. Arch Environ Health; 39: 101-6.

12. Sarlo K and Kirchner DB (2002): Occupational asthma and allergy in the detergent industry: new developments Curr Opin Allergy Clin Immunol; 2: 97-101.

13. Sarlo K (2003): Control of occupational asthma and allergy in the detergent industry Ann Allergy Asthma Immunol; 90 (5Suppl. 2): 32-4

14. Schweigert MK, MacKenzie DP and Sarlo K (2000): Occupational asthma and allergy associated with the use of enzymes in the detergent industry - a review of the epidemiology, toxicology and methods of prevention Clin Exp Allergy; 30: 1511-8

15. Statistical package for Social Science (SPSS) 15.0 for windows; SPSS Inc, Chicago, IL, 2001.

16. Subbarao P, Mandhane PJ and Sears MR (2009): Asthma: epidemiology, etiology and risk factors, CMAJ: 181-90.

17. Van Rooy FG, Houba R, Palmenn N, Zengeni MM, Sander I, Spithoven J, Rooyackers JM and Heederik DJ (2009): A cross-sectional study among detergent workers exposed to liquid detergent enzymes. Occup Environ Med; 66(11):759-65.

18. Vanhanen M, Tuomi T, Tiikkainen U, Tupasela O, Voutilainen R and Nordman H (2000): Risk of enzyme allergy in the detergent industry. Occup Environ Med ;57:121-5

19. Vanhanen M (2001): Exposure, sensitization and allergy to industrial enzymes. People and Work Research Reports 46. Finnish Institute of Occupational Health. Department of Pulmology, Helsinki University Central Hospital. Helsinki. 